\title{
慢性疾患とともに生きる青年のノーマリゼーション
}

\author{
中野 綾美*

\section{Normalization among the Adolescent Living with Chronic Illness}

Ayami Nakano

Kochi Women's University

Assistant Professor

\begin{abstract}
Abstruct
The purpose of this study was to identify the demention of normalization and normalization process among adolescent patients with chronic illness. Thirty adolescent subjects with either asthma or diabetes mellitis were interviewed.

Findings include the identification of three dimentions of normalization.these three dementions are :(1) the adolescent's self concept;(2) the evaluation of the situation; and (3) activities of daily living. These dementions were made up fourstages with similar processes. First the adolescent experiences confusion. Next he or she beings to establish a conceptual foundation. Then comes the ability tomake some personal decisions. And finally, the chronically ill adolescent is able to examine multiple options and negotiate complex decisions and judgments in a creative manner. Perhaps because of the adolescent's developmental stage, normalizing process of the adolescent's self concept was found to be unique.
\end{abstract}

\section{要 旨}

本研究は, 慢性疾患とともに生きる青年のノーマリゼーション現象がどのようなものであるかを 明確にすることを目的とした。慢性疾患のために現在外来通院を行っている中学生・高校生 30 名を 対象に，面接法によりデー夕を収集し，質的分析を行った。

分析の結果，ノーマリゼーションを形づくる局面として(1)病気とともにある自己を形成する局面 (2)状況判断の局面(3)ノーマリゼーション行動の局面という3つの局面が抽出された。ノーマリゼー ションは，4つの段階を経てプロセスをなして進展していた。青年は，ノーマリゼーションのプロ セスが進展するに従って, 独自に生み出したノーマリゼーション行動を駆使しながら日常生活を営 み, 健康な自己と病気の自己という分裂した自己を持つ苦悩を乗り越え, 統合した自己を確立して いた。本究結果から，ノーマリゼーションを「病気とともにある自己をふまえて，個人が自ら作り 出した判断基準に基づき現実を検討して, 自らの生活を普通の生活に近づけ, 社会的に生きていく ための戦略を創造していく過程である」と提案する。 


\section{I 、はじめに}

慢性疾患が増加してきた今日, 看護者は患者 を単に受け身的な存在としてではなく, 主体的 な人間として捉えた実践を展開し始めている。 研究においても，患者の主体性に注目したセル フケア ${ }^{122) 31}$ や対処に関する研究(45)6)が重ねられ ている。セルフケアや対処と並んで，主体的に 生きる存在として慢性疾患患者を捉えているも う一つの視点が, ノーマリゼーションであろう。 地域サイドからもノーマリゼーションの重要性 が叫ばれているが, 病気を持ちながら生きてい る人々が, 病気に屈することなく, 自らの生活 を創造的に築いていくという病者自身の取り組 みとしても重要であると考える。

本研究は, 慢性疾患とともに生きる青年の) ーマリゼーション現象がどのようなものである かを明確にすることを目的とした。

\section{II ・ノーマリゼーションに関する文献検討}

ノーマリゼーションに関する研究は, 慢性疾 患患者を抱える家族を対象に行なわれてお り，788)9慢性疾患患者自身に焦点をあてた研究 は, Strauss (1984) ${ }^{10}$ による研究のみであった。 ノーマリゼーションは 3 つ立場から論じら れている。第一は，患者抢よび家族が自分達を 普通であると認知することをノーマリゼーショ ンと捉える，認知の側面を強調する立場である。 例えば, Schrwartz ら (1957) ${ }^{11) や D a v i s ~ ら ~}$ (1963) ${ }^{12)}$ は, 子どもの正常ではない側面を軽視 したり合理化する，あるいは深刻さを否認する ことを, ノーマリゼーションの一部として位置 づけている。また, Roskies (1972) ${ }^{13)}$ は「サリド マイドの子どもを持つ母親が，障害があるにも 関わらず，子どもを普通の子どもとして認知し ていくこと」をノーマリゼーションと捉えてい る。

第二は，患者および家族が他者に自分達の正 常性を強調して示したり, 普通の生活を送るた めに努力や工夫する行動をノーマリゼーション と捉える, 行動を強調する立場である。この立 場は, Davis (1963) ${ }^{14)}$, Birebaum $(1970,1971)$, Voysey (1972), Anderson(1981) らの研究によ
り発展してきている。例えば, Anderson(1981) は「子どもの身体の異常性を最少限に見せる」 行動, Robinson(1984) ${ }^{15}$ は「通常の活動に参加 する」行動などを重視している。

第三は社会との融合を強調する立場であり, 社会や仲間集団などの社会システムに融合して いく努力をノーマリゼーションと捉えている。 この立場は, Strauss (1975) ${ }^{16) や ~ H o l a d a y ~}$ $(1984)^{17)}$, Deatrick (1986) ${ }^{18)}$ らの慢性疾患およ び発達遅滞の子どもを持つ家族を対象にした研 究により発展してきており，子どもをとりまく

「家族, 仲間, 学校, 地域社会などの社会シス テムに融合する」という面が強調されている。

このように3つの立場からノーマリゼーショ ンが論じられているが，いずれも側面的な捉え であり，ノーマリゼーションを全体として捉え 定義づけたものではない。まして，青年を対象 とした研究は見あたらなかった。したがって， 慢性疾患とともに生きる青年のノーマリゼーシ ヨンを明らかにするためには, 帰納的な研究方 法が適切であると考えた。

\section{III. 研究方法}

\section{1. 研究対象者}

外来通院中のインスリン依存型糖尿病および ぜんそくを持つ中学生, 高校生を対象とした。 対象を選択するにあたり，面接法によるデー夕 収集のため, コミュニケーションの障害，およ び発達遅滞の認められるものは除外し, 同意の 得られた者を対象とした。

\section{2. 研究デザイン}

本研究では, 慢性疾患とともに生きる青年の ノーマリゼーション現象の明確化を試みている。 既存の文献を検討した結果, 青年のノーマリゼ ーションについて研究が行われていなかったこ と, また, 本研究が個人の極めて主観的な体験 を研究していることから, 現象を包括的にとら えることのできる, 㷌納的手法による質的因子 探索型研究を行った。 


\section{3.デー夕収集方法およびデー夕収集期間}

デー夕を収集するにあたり，面接技術を洗練 化する目的で糖尿病サマーキャンプに参加し, 6 人の中学生・高校生を対象に面接を行なった。 面接結果を基に，半構成質問紙を作製し，これ を用いて，平成 1 年 7 月 26 日から 10 月15日まで, 東京都内の某国立病院の小児科外来, および小 児専門病院の外来で面接を行った。面接内容は, 対象者の同意を得て録音した。面接時間は，40 分から150分におよび平均面接時間は80分であ つた。

\section{4. 分析方法}

録音した面接内容は逐語記録し, フィールド ノートを作成した。文脈にそって対象者が語つ た内容の意味をコード化し分析を行った。さら に，類似したコードを分類しカテゴリー化を試 みた。尚，分析は指導者にスーパービジョンを 受けながら進めた。

\section{IV. 結果}

\section{1. 対象者の特性}

対象者は男子 15 名，女子 15 名，平均年齢 15.0 歳, 平均発病年齢 5.5 歳であり, 発病後平均 9.6 年が経過していた。尚診断名は，インスリン依 存型糖尿病17名, ぜんそく13名であった。

2. 慢性疾患とともに生きる青年のノーマリゼ ーション現象の構造

ここでは,ノーマリゼーション構造の全体像 を記述し, その後で模範例を提示する。慢性疾 患とともに生きる青年のノーマリゼーションは

「病気とともにある自己を形成する局面」「状況 判断の局面」「ノーマリゼーション行動の局面」 の 3 局面から形づけられていた（図 1 参照)。

\section{1 ）病気とともにある自己を形成する局面}

この局面は, 青年が病気を持つ自己の中に正 常性を見いだし統合された自己を確立していく 局面である。青年は, 自己を評価する基準を活 用しながら, 㷌属感の求め, 病気を受容しつつ, 病気の自己を時間的に展望しながら捉えていっ

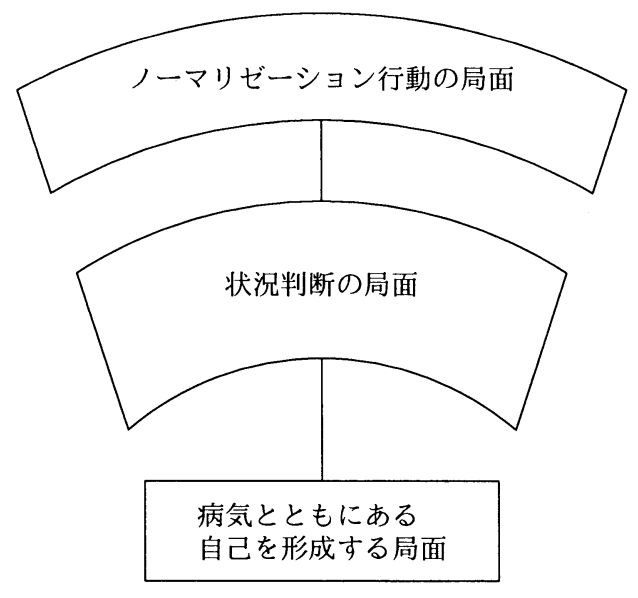

図1ノノマリゼーションの構造

ていた。すなわち，この局面は(1)自己評価の基 準(2)㷌属感の希求(3)病気の受容(4)時間的展望の 仕方という要素により規定されていた（表 1 参 照)。

\section{2 ) 状況判断の局面}

この局面は, 身体状態や周囲の人々の心, そ して自己の行動特性を読みとりながら, 独自の 判断基準を用いて，どのような日常生活を過ご していくかを決定しく局面である。この局面は, (1)身体状態の読み(2)日常生活行動の読み(3)自己 の行動特性の読み(4)周囲の人々の心の読み(5)判 断基準の要素からなっていた（表 2 参照）。

\section{3 ) ノーマリゼーション行動の局面}

この局面は, 青年が可能な限り普通の日常生 活を送るためにとる行動群からなる局面である。 具体的な行動には, 依存行動, 自立行動, 正常 性の印象づけ行動, 異常性の活用行動, 闘争行 動, 維持行動, 優先順位の決定行動, 調整行動, 合理化行動, 否定行動, 操作行動, 防御行動, サポートの活用行動, オープンネス行動, セミ オープンネス行動, クローズネス行動らが含ま れていた（表 3 参照）。

3. 慢性疾患とともに生きる青年のノーマリゼ ーション現象のプロセス

青年のノーマリゼーションを形作る局面の病 気とともにある自己を形成する局面と状況判断 の局面は，それぞれ段階を形づくりながら，プ ロセスをなして進展していた。 


\begin{tabular}{|c|c|c|c|c|c|c|c|c|}
\hline 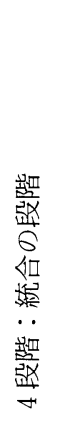 & 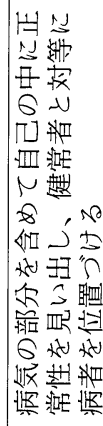 & 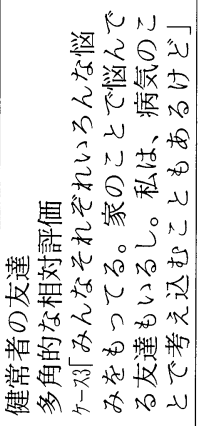 & 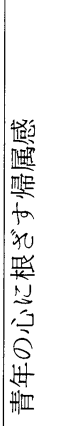 & 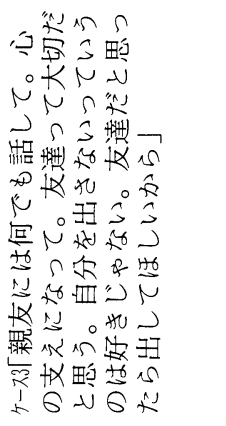 & 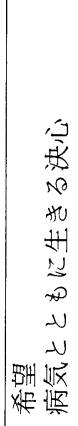 & 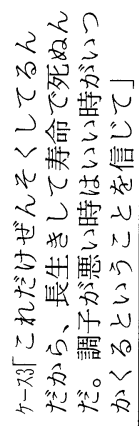 & 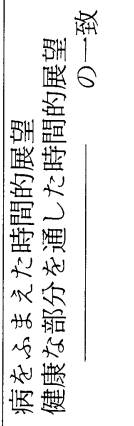 & 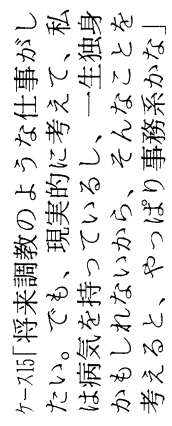 \\
\hline 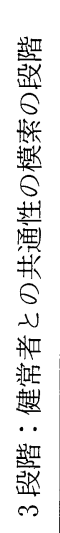 & 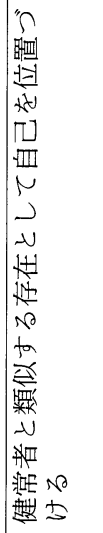 & 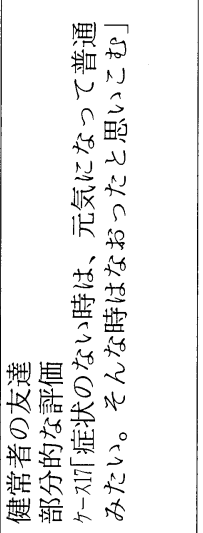 & 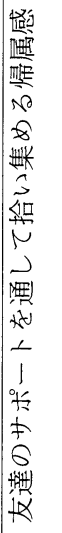 & 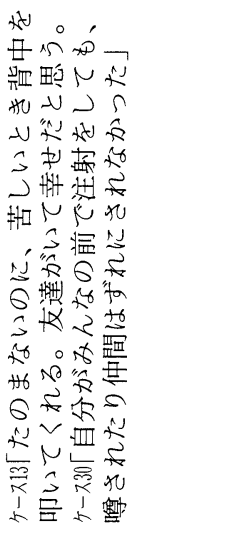 & 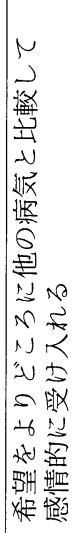 & 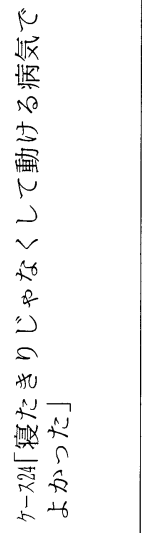 & 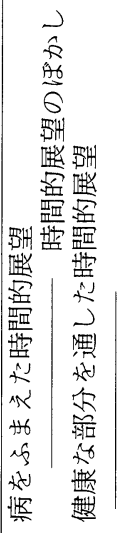 & 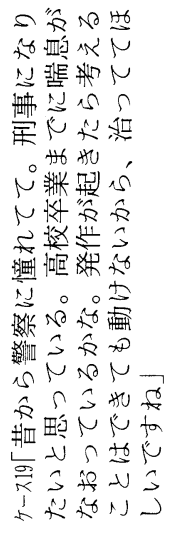 \\
\hline 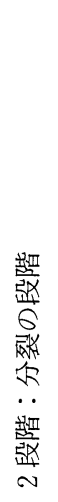 & 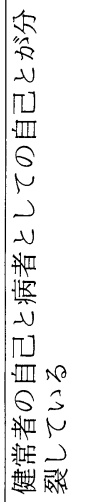 & 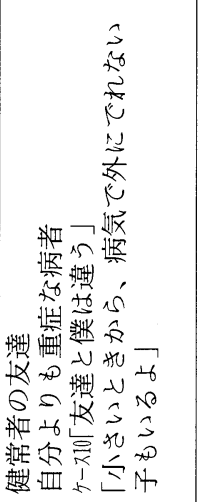 & 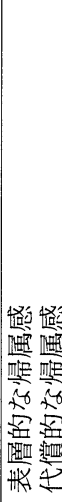 & 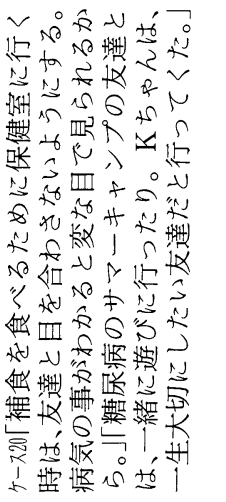 & 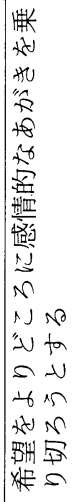 & 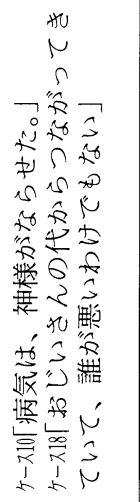 & 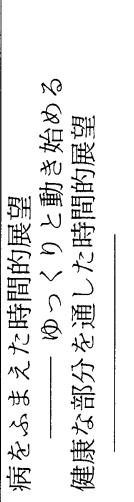 & 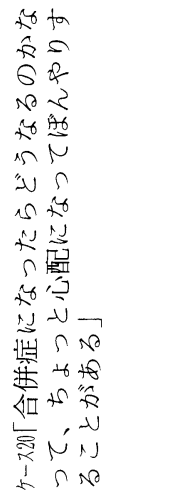 \\
\hline 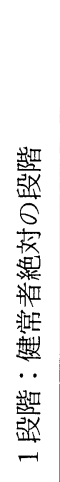 & 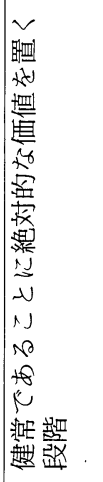 & 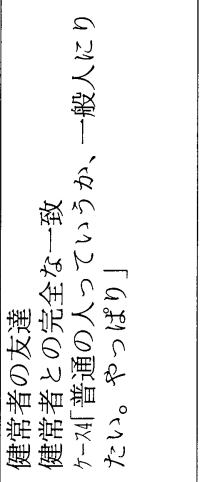 & 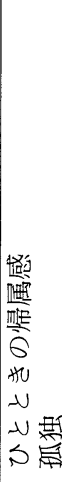 & 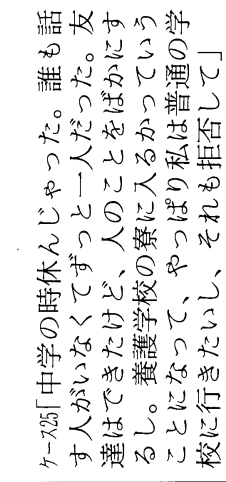 & 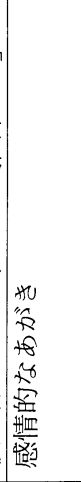 & 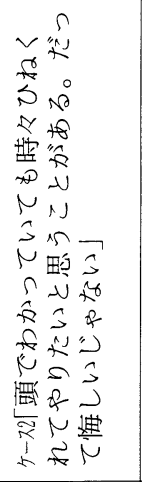 & 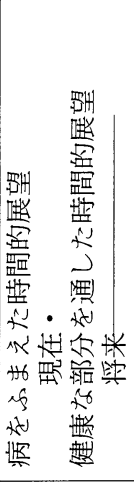 & 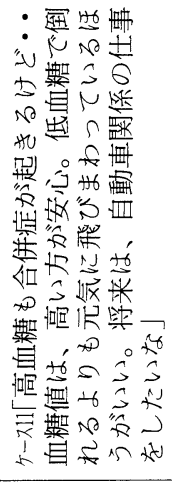 \\
\hline 䊬 & 通 & 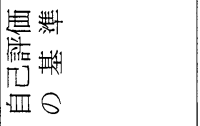 & \multicolumn{2}{|c|}{ 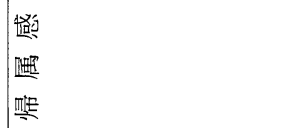 } & \multicolumn{2}{|l|}{ 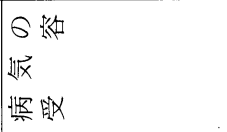 } & \multicolumn{2}{|l|}{ 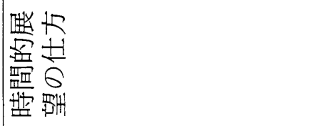 } \\
\hline
\end{tabular}




\begin{tabular}{|c|c|c|c|c|c|c|}
\hline 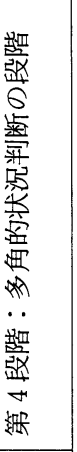 & \multirow{2}{*}{ 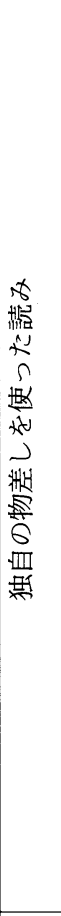 } & \multirow{2}{*}{ 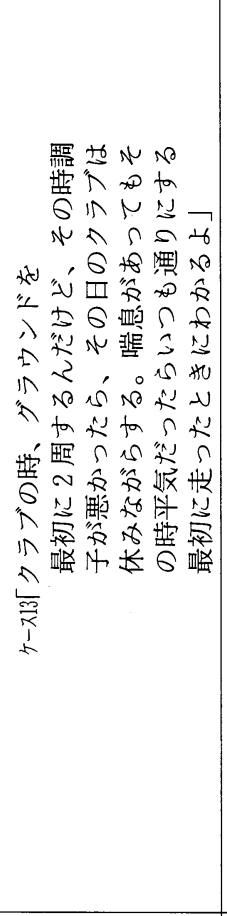 } & \multirow{2}{*}{ 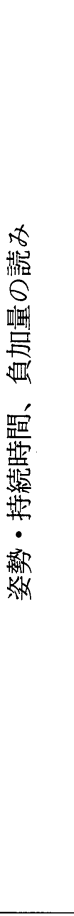 } & \multirow{2}{*}{ 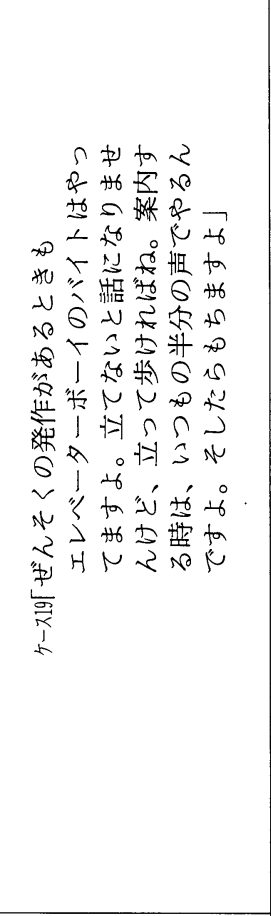 } & 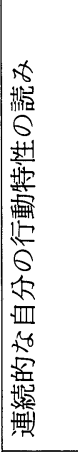 & 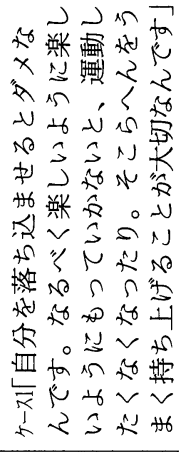 \\
\hline 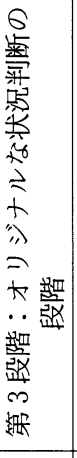 & & & & & 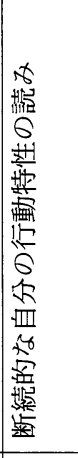 & 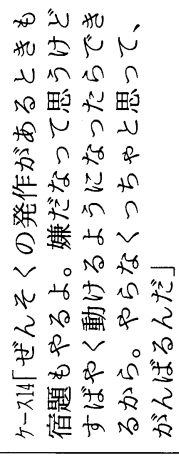 \\
\hline 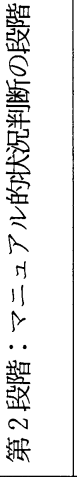 & 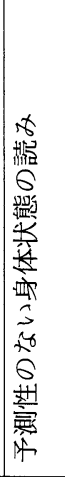 & 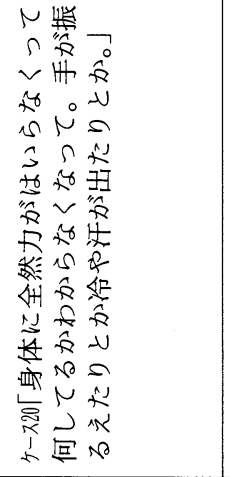 & 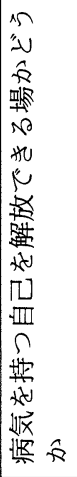 & 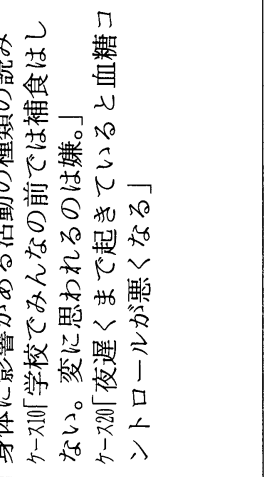 & 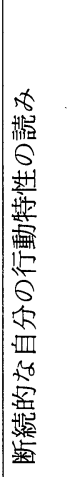 & 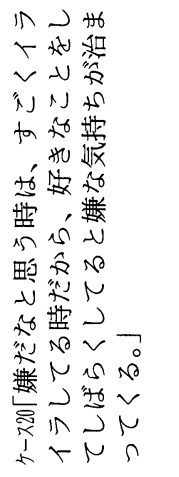 \\
\hline 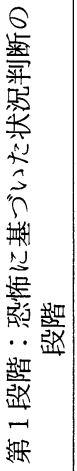 & $\overrightarrow{x^{6}}$ & 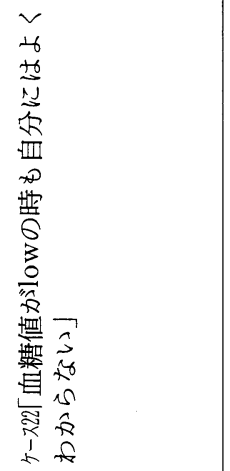 & 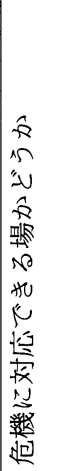 & 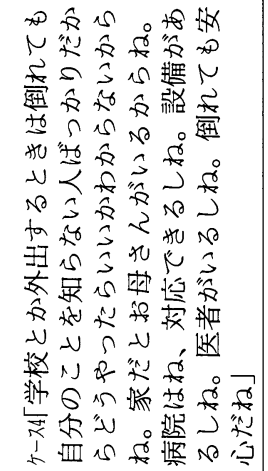 & 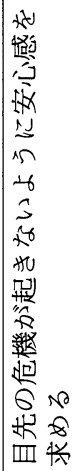 & 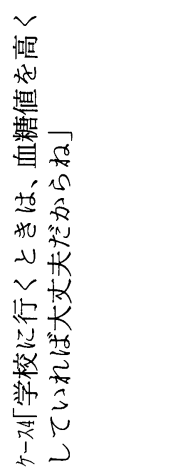 \\
\hline $\int_{\text {䑫 }}$ & 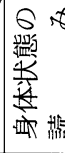 & & 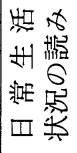 & & 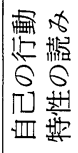 & \\
\hline
\end{tabular}




\begin{tabular}{|c|c|}
\hline 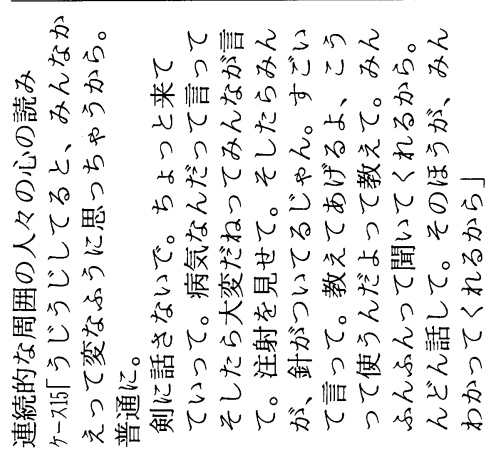 & 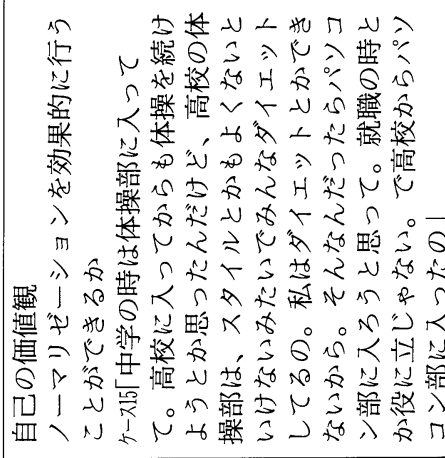 \\
\hline 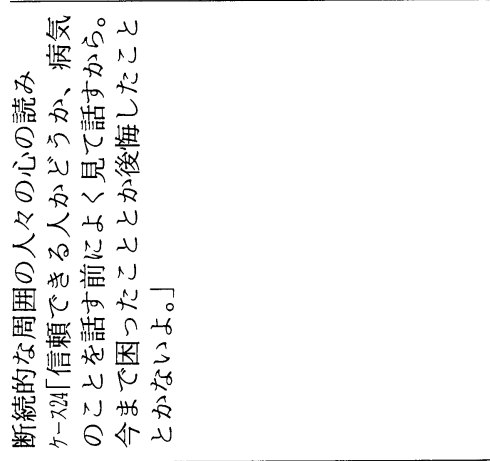 & 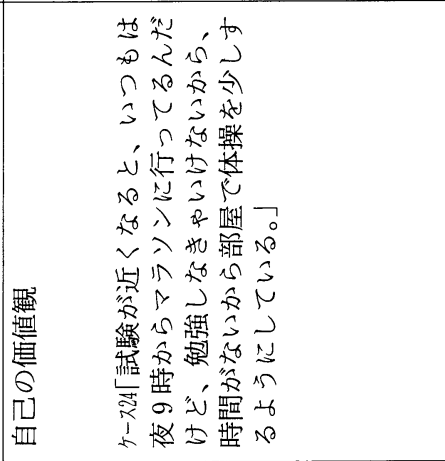 \\
\hline 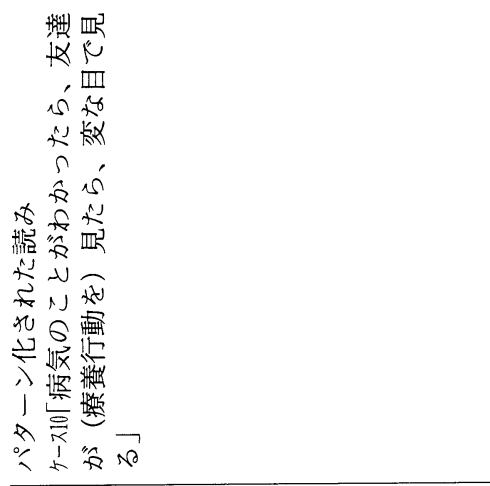 & 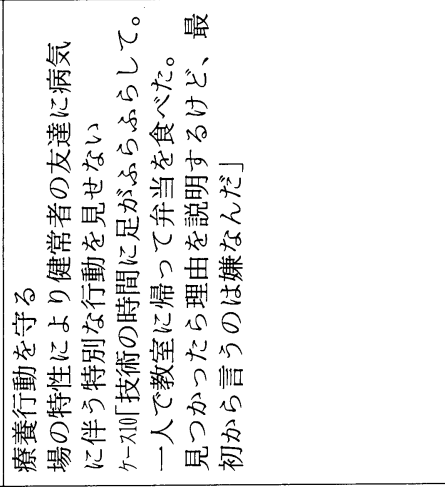 \\
\hline 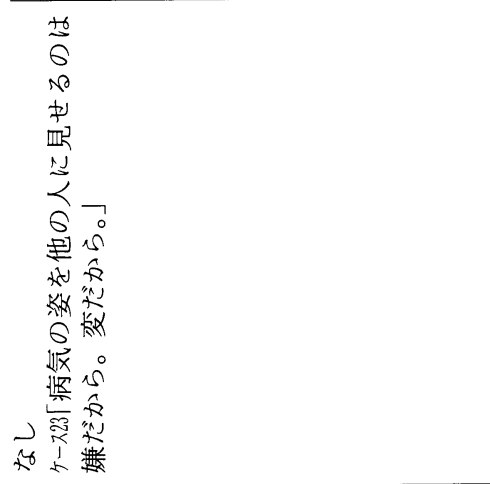 & 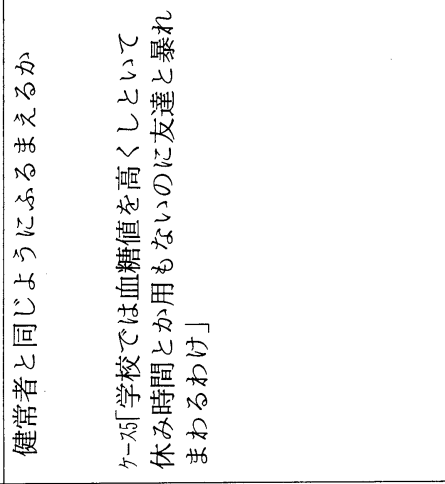 \\
\hline 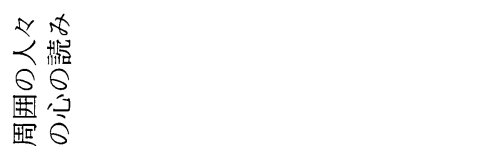 & 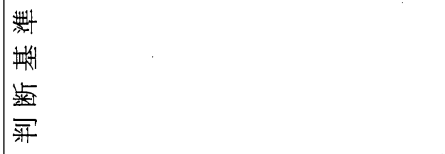 \\
\hline
\end{tabular}




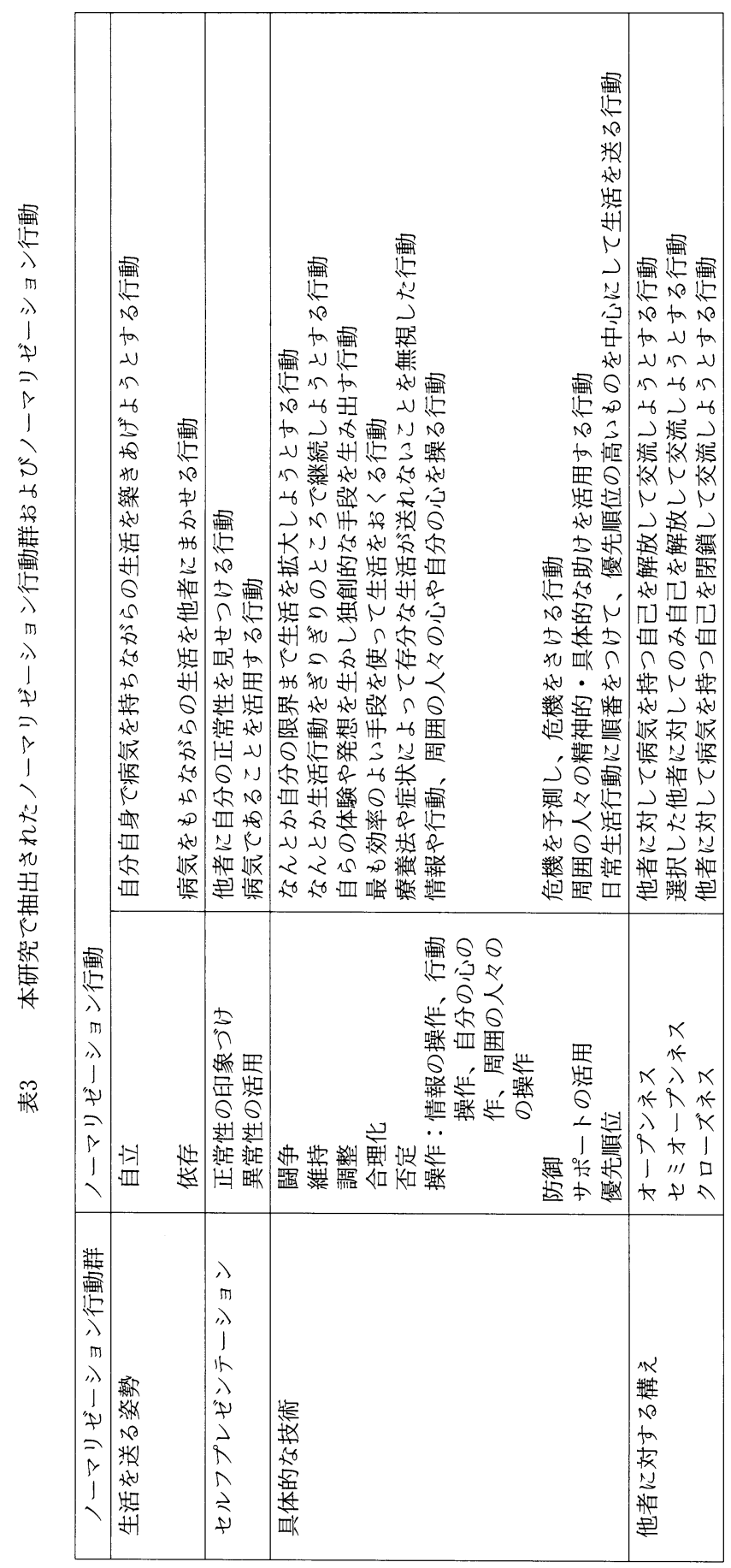




\section{1）病気とともにある自己を形成する局面} この局面は, 第 1 段階: 健常者絶対の段階, 第 2 段階: 分裂の段階，第 3 段階: 健常者との 共通性の模索の段階, 第 4 段階: 統合の段階を 経て進展していた。それぞれの段階の具体的な 模範例を表 1 に示した。健常者絶対の段階は, 「俺は, 普通の人っていうか,一般人になりたい」 (ケース 4 ) という言葉からわかるように, 健常 者に絶対的な価值を置いている段階である。自 己を評価する際に用いる基準は健常者に置き, 健常者との友達の一致化を思考して正常性を見 いだそうとしていた。そのため,「クラブが終わ ったら友達と一緒に食べにいく。自分だけ食べ ないっていうわけにはいかない」(ケース11)と いうように，身体を犠牲にしてまでも㷌属感を 持とうとしていた。しかし「ずっと一人だった ……養護学校の寮じゃなく, やっぱり普通の学 校に行きたいし」(ケース25) というように，健 常者との友達とも病気の仲間とも㷌属感を獲得 することができず, 最も孤独な状態に置かれて いる。病気の受容については「心に区切りがつ いていない」(ケース11),「頭でわかっていても 時々ひねくれてやりたいと思うことがある。だ つて悔しいじゃない」(ケース25)など, 理性的 には自分が病気であることを理解し認めている にも関わらず，感情的には，自分が病気である ことを受け入れることができずにあがいている と言える。将来に対しては, 病をふまえての時 間的展望を行うことができず, 健康な部分を通 しての時間的展望のみをしていた。

分裂の段階は, 健常者の自己と病者としての 自己が分裂している段階である。健常者の友達 を基準として病気を持つ自己を評価し「自分は みんなとは違う」(ケース10) と評価し，その一 方で, 病気である友達を基準に評価して正常性 を見いだそうとしていた。

健常者との共通性の模索の段階は, 病気であ るために健常者とは対等ではない部分があるこ とを認めつつ, 自己のポジティブな部分に注目 し，健常者と類似した者として自己をとらえる 段階である。青年は「症状のない時はもう元気 になって普通みたい。そんな時はもうなおった と思いこむ」(ケース17）というように，症状の
ない時の自己を健常者と類似する自己として位 置づけたり，「自分で判断して，自分でできると 思った時は積極的に行う」(ケース14), 「自分も 本当によくやってきたと思う」(ケース28)など, 病気とともに生きる中で育んできた自分の能力 や努力に注目することで, 自己の中に正常性を 見いだしていた。健常者との友達の帰属感を求 めているが, それは受け身的で, 友達のサポー トを通してかみしめる㷌属感である。また, 病 いへの構えは，第 2 段階で発見した希望をより どころに，自分の病気と他の病気を比較して病 気を受け入れようとしていた。将来に対しては, 病いをふまえての時間的展望はさらに健康な部 分を通しての時間的展望に近づくが, 病をふま えての時間的展望をぼやかすことで，完全に一 致することを妨げている。

統合の段階は, 病気の部分を含めて自己の中 に正常性を見いだし，健常者としての自己と病 者としての自己を統合していく段階である。周 囲の人久から「病気だけど(健康な)自分達と同 じ」(ケース 1 )という肯定的な評価を受けたこ とを自分に繰り返し言い聞かせたり，他者に語 ることにより，第 3 段階で獲得した拾い集めた 正常性を基に, 健常者との多角的な相対評価を 行うことが可能になり, 受け身的な, 友達の少 ポートを通してかみしめる帰属感から, より力 強い能動的な青年の心に根ざす帰属感になって いる。病気の受容は, 希望を持ちながら, 病気 とともに生きる決心をしていた。

\section{2 ) 状況判断の局面}

この局面は，第 1 段階：恐怖に基づく状況判 断の段階，第 2 段階: マニュアル的状況判断の 段階, 第 3 段階: オリジナルな状況判断の段階, 第 4 段階: 多角的な状況判断の段階へと進展し ていた。それぞれの段階の具体的な模範例を表 2 に示した。表 2 に示すように, 恐怖に基づく 状況判断の段階は「夜は血糖值が高くても気に ならないね。寝ている時は低血糖になってもあ れだしね」(ケース11)というょうに，青年は病 気からくる恐怖に打ちまかされており，予測さ れる危機にとらわれている。状況判断は, この 恐怖によって影響される。そのため, 身体状態 の読みができておらず, 日常生活行動の読みは, 
活動の特性（持続時間・負加量・姿勢など）を考 慮するのではなく，危機が発生した場合に対応 できる場であるかどうかを読みとっていた。自 己の行動特性の読みは, 目先の危機に対する安 心感を基にして読みとっていた。周囲の人々の 心の読みは，自分の恐怖心にとらわれているた めに，他者の心を読みとる余裕を持っていなか つた。判断基準は，危機に陥らずに日常生活を 過ごすことができるか, 自分は健常者の友達と 同じようにふるまえるかどうかということを基 準に用いていた。

マニュアル的状況判断の段階では, その時点 で体験している症状に基づいて身体状態の読み を行っている。しかし「身体に全然力が入らな くなって。何してるかわからなくなって。手が 振るえたり冷や汗が出たりとか」(ケース20) と いうように，長期的な展望が欠如しているため に，予測性を伴っていない。原則的な知識を基 に生活行動を大きく分類し，身体に影響がある 生活行動の特性や療養行動を必要とする生活行 動の特性に焦点をあてて読みとっていた。また， 病気を持つ自己を開放できるかどうかという視 点からの場の特性を読みとっている。周囲の 人々の心の読みは，病気がわかれば変な目で見 られるという怯えにとらわれているために， 個々の人に生じる変化を読みとるにはいたって いなかった。青年は，いくつかの原則的な視点 から現実を見つめ,「療養行動を守ること」と「健 常者の友達に病気に伴う特別な行動をみせな い」という 2 つ基準を用いて判断していた。 すなわち，原則的な療養行動を守るという基準 を一貫して用いながら，活動する場の特性によ り，適宜，健常者の友達に病気の自分を見せな いという基準を用いていた。

オリジナルな状況判断の段階は, 自分が体験 の中から身体状態や自己の行動特性に関する 「独自のものさし」を生みだし，それを活用し ていたことが特徴である。「クラブの時グラウン ドを最初に 2 周する。その時調子が悪かったら その日は休みながらする。その時平気だったら いつも通りにする」(ケース13)というように, 青年は, 毎日の生活の中で, 日常生活行動とそ れにより生じた身体状態の変化を繰り返し対比
させることにより作り出した，「独自のものさ し」よる読みとりに基づいて行動し，その結果 を再評価していた。そうすることである程度予 測可能なものさしとなっている。独自のものさ し」を発展させるためには, 日常生活行動の特 性である，姿勢・持続時間・負荷量などをより 正確に読みとることも要請される。また，先の 第 1 ・第 2 段階とは異なり，行動するまえに， 周囲の人々の心を読みとることができている。 しかし，4 段階の青年のように，微妙に動く人 の心を読みとるにはいたっていない。また，判 断基準として自己の価值観を用いるため, 自分 にとって重要なことと療養行動を行うことを常 に天科にかけ，自分にとってどちらが価値があ ることなのかを判断している。

多角的な状況判断の段階は, 病気を持つ自分 の姿を他者に見せる際に，他者の中に生じる心 の変化を刻々と読みとっていることと，ツボを おさえた効果的なノーマリゼーション方向に向 かった，判断基準を用いていることが特徴であ る。「うじうじしてると, みんなかえって変なふ うに思っちゃうから。普通に。真剣に話さない で。……病気なんだって言って。注射を見せ て。そしたらみんなが針がついてるじゃん。す ごいって言って。こうやって使うんだよって教 えて」(ケース15) というように，他者の中に生 じる心の変化を刻々と読みとり，現実を見据え て多角的に状況を判断するようになっている。

\section{V. 考察}

本研究結果を基にノーマリゼーションの概念 化を行い，次に青年のノーマリゼーションの特 徵について考察する。

\section{1.ノーマリゼーションの概念化}

本研究結果から得られたノーマリゼーション の 3 つの局面とノーマリゼーションに関する既 存の研究およびKnafl (1986) ${ }^{19)}$ の基準を比較検 討し，ノーマリゼーションの概念化を試みる。

本研究結果と既存の研究のノーマリゼーショ ンの捉え方を比較すると，病気とともにある自 己を形成する局面は, 


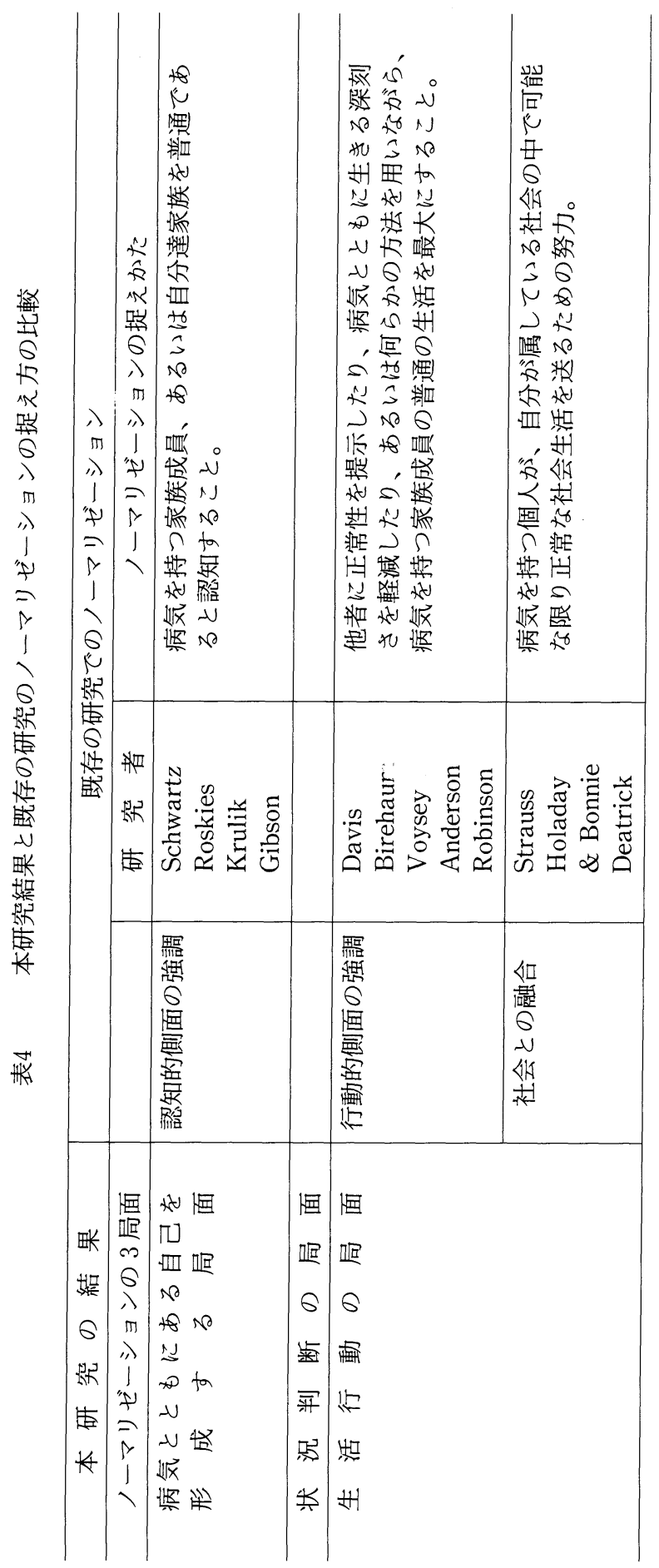


Schwartz $(1957)^{20)}$ にりり明らかにされ, Roskies (1972) ${ }^{21)}$, Krulik (1988) ${ }^{22)}$, Gibson $(1988)^{23)}$ により発展してきた認知的側面を強調 する見解と一致していると言えよう。また, 病 気とともにある自己を形成する局面は, Knafl $(1986)^{24)}$ のノーマリゼーションを織りなす基準 である「機能障害を認知する」「家族や本人が自 分自身を正常であると認知する」「生活は本質的 には正常であると認知する」と一致している。 病気とともにある自己をどのように捉えるかに より,それに続く状況判断の局面, 具体的な生 活行動に関するノーマリゼーション行動の局面 が規定されてくるので, この局面は, ノーマリ ゼーションの基礎となる重要な局面であると考 える。

状況判断の局面は, 本研究結果から導き出さ れた新しい局面である。状況判断の局面は, 病 気とともにある自己に基づいて, 生活を常態化 するノーマリゼーション行動を展開する場合に なくてはならない，つなぎ目を果たしている局 面であると考える。この局面はKnafl $(1986)^{25)}$ のノーマリゼーションの織りなす基準である, 状況の影響を最小限に認知すると関連している。 状況判断の局面の結果で述べたように, 青年は, 状況の影響を最小限に認知するというよりは, むしろ，ありのままの現実を多角的に見据えて， 身体の状態の読み, 日常生活行動の読み, 自分 の行動特性の読み, 周囲の人々の心の読みを行 い，現実を見極めた上で多彩なノーマリゼーシ ヨン行動を展開していた。したがって, Knafl $(1986)^{26)}$ の示した状況の影響を最小限に認知す るというよりはむしろ，ノーマリゼーションを 進展させていく上では，現実を多角的に見据え ることが重要であると考える。

ノーマリゼーション行動の局面は, Davis $(1963)^{27)}$, Birebaum $(1970,1971)^{28)}$, Voysey $(1972)^{29)}$, Anderson (1981) ${ }^{30)}$ らの行動的側面を 強調する見解および社会との融合を強調する見 解と一致するものである。慢性疾患による生活 への影響に対して, 青年は, 16 のノーマリゼ ーション行動を駆使して立ち向かっていた。こ の局面は, $\operatorname{Knaf1}(1986)^{31)}$ ノーマリゼーショ ンを織りなす基準である,「正常であることを第
三者に表すための行動をとる」を包含している 考える。

以上のことから，ノーマリゼーションを「病 気とともにある自己をふまえて, 個人が自ら作 り出した判断基準に基づき現実を検討して, 自 らの生活を普通の生活に近づけ, 社会的に生き ていくための戦略を創造していく過程である」 と提案する。過去の研究において, ノーマリゼ ーションの定義があいまいで様々に定義づけら れていたのは,ノーマリゼーションのひとつの 局面にスポットをあててその現象を導きだし， 定義づけているためと考える。

\section{2. 青年のノーマリゼーションの特徵}

青年のノーマリゼーションは, 帰属感の希求 を原動力としていること, 生き方を模索してい ることなど, 青年期の発達段階を反映した特徵 がみられた。

（1）原動力としての帰属感の希求

慢性疾思を持つ青年にとって, 㷌属感の希求 はノーマリゼーションの原動力になっている。 例えば，ある青年は，友達と一緒に野球部の一 員でありたいという願いが原動力となっていた

(ケース13)。このような態度は, ケース全体に 共通したものであり, 青年の行っているノーマ リゼーションの中に脈々と波打っているもので あった。これは, 発達課題である自我同一性の 確立に取り組んでいる青年の, 絶望的なまでに 帰属感を求めている青年の特性を反映している と言える。帰属感を求めて, 時には身体を犠牲 にしてまでもノーマリゼーションを全うしょう とするのは, 青年期は, 家族という集団から, 仲間, 学校, 地域社会へと, 彼らにとって重要 な生活の基盤が拡大しており, 様々な役割実験 をしながらその中で生きていくことのできる自 分を見出していこうとしている, 青年期の発達 的特徵を反映しているといえる。

(2) 生き方の摸索

青年のノーマリゼーションのもうひとつの特 徵は, 病気とともにある自己を形成していく中 で, 病いをふまえての時間的展望と健康な部分 を通しての時間的展望により，自分の将来を見 つめ生き方を模索していたことである。Laing 
（1960）は，病者は，健康な自己に基づいて認知 する世界と病いを抱えた自己に基づいて認知す る世界という異なるふたつの世界の中で生きて いかねばならないと，分裂した自己を持つこと の苦悩について論じている。まさしく, 慢性疾 患を持つ青年は，自我確立期に病気を持つ自己 と健康な自己という分裂した自己を持つ苦悩を 乗り越え, 統合した自己を確立するという課題 に直面していると考えられる。青年は, ノーマ リゼーションのプロセスが進展するに従って, 慢性疾患による影響に打ちのめされるのではな く, 独自に生み出したノーマリゼーション行動 を駆使しながら日常生活を営む中で，統合した 自己の確立を試みている。さらに, 自ら病気と ともに生きてきた人生を振り返り，その中から 将来の自分の生き方を模索している。

\section{VI. 看護実践への手がかりと今後の課題}

本研究の結果から, 慢性疾患を持つ青年の理 解および看護活動に関する以下のような手がか りを得たと考える。

(1)青年は, 慢性疾患とともに生活していく中で 独自のものさしを作りだし, 独自の戦略を立て て生活を送っている。したがって, 適切な看護 が展開できるかどうかは, 個々の青年が持つ独 自のものさしを看護者が理解することから始ま る。

(2)青年が自らの生活の中から生み出したノーマ リゼーションの技を看護者が学ぶことにより, 慢性疾患に圧倒され途方にくれている青年に具 体的なアプローチを展開できる。

(3)青年がノーマリゼーションのどの段階にいる かについてのアセスメントの視点として活用で きる。

しかし, 本研究では, 以下のような限界があ ると考えられる。まず, 本研究では, 研究者自 身がデータ収集の測定用具となる。指導者の基 で指導を受けながら研究を進め, 信頼性を高め るよう努めたが, 歪みが生じることは避けられ ない。また, 対象者について, 発病後の期間が 5 年以上の者が 29 名, 発病後 2 年の者が 1 名と, 発病後の期間に偏りがる。

今後はさらに症例数を重ね, 経時的研究を行
うことによって, より信頼性のある研究結果と していく必要かあると考える。

謝辞

本研究を行うにあたり, ご指導頂きました聖 路加看護大学常葉恵子教授, 兵庫県立看護大学 片田範子教授に深謝いたします。そしてご協力 いただきました病院の看護部長はじめ看護婦の 皆様, 病気とともに生きるとはどういうことか を語り，多くのことを教えてくださった中学生， 高校生の方々に心からお礼申し上げます。

引用文献

1) 岡田麗江他：わが国の看護におけるセルフ ケアについての考察 オレム看護論との比 較品, 大阪大学医療技術短期大学部研究 紀要, 自然科学編, 11, 45-62, 1983.

2 ) 草刈淳子：看護ケアの質保証のための概念 モデルセルフケアの成立過程と援助行動を 例として，看護教育，28(10)，603-613，

3 ) 竹内美恵子 : セルフケアを主題とした看護 研究の現状, 看護研究, 20(5)，438-448, 1987.

4 ) 岡谷恵子 : 手術を受ける患者の術前後のコ ーピングの分析, 看護研究, 21(3), 261$268,1988$.

5 ) 中西睦子: 退所に関する研究文献概観, 看 護研究, 21(3)，210-224，1988.

6 ) Sutherland, Suzanne : Burned Adolescents' Descriptions of Their Coping Strategies, Heart \& Lung, 17(2), 150157, 1988.

7 ) Schawrtz, Charlotte Green : Perspective on Deviance- Wives' Definitions of Their Husbands' Mental Illness, Psychiatry, 20, 257-291, 1957.

8 ) Anderson, Joan M : The Social Construction of Illness Experience Families with a Chronically Ill Child, Journal of Advanced Nursing, 6, 427-434, 1981.

9 ) Gibson, Cheryl : Perspective in Parental Coping with a Chronically Ill Child The Case of Cystic Fibrosis, Issue in Compre- 
hensive Pediatric Nursing, 11, 33-41, 1988.

10) Strauss, Anselm L., et al : Chronic Illness and the Quality of Life 2nd, 1984, 南裕 子監訳，慢性疾患と生きるケアとクオリテ ィ・オブライフの接点, 医学書院, 1987.

11) Schawrtz, Charlotte Green : 前掲論文 7.

12) Davis,Fred:Divance Disavowal The Manegment of Strained Interaction by the Visibly Handicapped,Social Problems, 9, 120-132, 1961.

13) Roskies, E. : Abnormality and Normality The Mothering of Thalidomide Children, Ithaca Carnell Unibersity Press., 1972.

14）Davis, Fred：前掲論文 12 .

15) Robinson, Carole A. : When Hospitalization Become an "Everyday Thing", Issues in Comprehensive Pediatric Nursing, 7, 363-370, 1984.

16) Strauss, Anselm L., et al：前掲論文 10 .

17) Holaday, Bonnie : Challendes of Rearing a Chronically Ill Child Caring and Coping, Nursing Clinic of North America, 19, 120-132, 1961.

18) Deatrick, Janet A. et al : The Process of Parenting a Chaild with a Disability Normalization through Accomodations, Jurnal of Advanced Nursing, 13, 1521, 1988 .

19) Knafl,Kathleen A. and Deatrick,Janet A. : How Families Manage Chronic Conditions An Analysis of the Concept of Normalization, Research in Nursing \& Health,9,215-222, 1986.

20) Schwartz, Charlotte Green : 前掲論文 7 .

21) Roskies,E.:Abnormality and Normality The Morthering of Thalidomide Children, Ithaca Carnell University Press., 1972.

22) Krulic, Tamar:Successful'Normalizing' Tactics of Parents of Chronically-Ill Chredren,Journal of Advance Nursing,
5, 573-578, 1980 .

23) Gibson,Cheryl：前掲論文 9 .

24) Knafl,Kathleen A. and Deatrick,Janet A.: 前掲論文 19 .

25) Knafl,Kathleen A. and Deatrick,Janet A.: 前掲論文 19 .

26) Knafl,Kathleen A. and Deatrick,Janet A.: 前揭論文 19 .

27) Davis, Fred：前掲論文 12 .

28) Birenbaum,Arnold:The Mentally Retarded Child in the Home and the Family Cycle Cycle, Jurnal of Health and Social Behavior, 13(March),80-89, 1972 .

29) Voysey, Margaret : Impression Management bu Parents eith Disabled Children, Journal of Health \& Social Behavior, 13 (March), 80-89, 1972.

30) Anderson, Joan M : 前掲論文 8 .

31) Knafl,Kathleen A. and Deatrick,Janet A.: 前揭論文 19 .

32) Laing,R.D.:The Divinded Self An Existential Study in Sanity and Madness,1960, 坂本健二訳, 引き裂かれた自己分裂病と分 裂病質の実存的研究, みすず書房, 1971. 